\title{
New Challenges and Opportunities for Lifelong Learning in South Africa
}

\section{SHIRLEY WALTERS}

To cite this article: SHIRLEY WALTERS (1999) New Challenges and Opportunities for Lifelong Learning in South Africa, Comparative Education, 35:2, 217-224, DOI: 10.1080/03050069927982

To link to this article: https://doi.org/10.1080/03050069927982

册Published online: 28 Jun 2010.

Submit your article to this journal 전

山 Article views: 131

Q View related articles $\asymp$

4 Citing articles: 5 View citing articles 지 
Comparative Education Volume 35 No. 21999 pp. 217-224

\section{New Challenges and Opportunities for Lifelong Learning in South Africa}

\section{SHIRLEY WALTERS}

ABSTRACT The imperatives for lifelong learning in South Africa are driven by its reinsertion into the global economy and by the social and political necessities of equity and redress after the years of colonialism, segregation and apartheid. It is therefore not surprising to find the discourse of lifelong learning infused into new policy documents. Utilizing Belanger's framework, which argues that lifelong learning is not a norm to prescribe but an empirical reality to analyze and reconstruct, the contexts for lifelong learning in South Africa are surveyed by focusing in on the state of initial education, adult education, and the learning environments. The framework, which acknowledges the daily lived realities of women and men, is a helpful way of retaining an holistic and integrated vision of lifelong learning and its humanistic, democratic goals. For lifelong learning in South Africa to deepen for more than a small group of well-educated, mainly urban, formally employed people, the author concludes that initial education, adult education and the learning environments of all the people will have to be improved. If this does not happen, then at least two polarized 'lifelong educations' will result.

\section{Introduction}

Driven by the imperatives of late capitalism, lifelong learning has become a key concept in the thinking about education and training worldwide. Candy (n.d.) points to the extraordinarily rapid pace of social, technological, cultural, economic, legal and educational changes throughout the world, combined with the increasing global connectedness of many societies and economies, which emphasize the need for people who are adaptable and responsive-in short, who are capable of continuing lifelong learning.

The even more dramatic changes in South African society render it particularly important for the South African educational system to produce lifelong learners and to provide for continuing learning throughout life. The imperatives for lifelong learning in South Africa are driven by its reinsertion into the global economy and by the political and social necessities of equity and redress after the years of colonialism, segregation and apartheid. It is therefore not surprising to find the discourse of lifelong learning infused into new policy documents.

Since the early 1990s South Africans have been engaged in intense education and training policy development. Every level of education and training, from general, further to higher education, has been rethought. Policy documents which have fed into legislative processes have been prolific. Lifelong learning entered the policy discourse during this time and has been mentioned in nearly all the policy documents. It has become a form of 'policy 
speak'. In this paper I will begin by presenting a framework for analysing lifelong learning. I will then describe the South African context and the opportunities and challenges there are to realize the visions of lifelong learning.

\section{The Concept of Lifelong Learning}

I have chosen to use a framework for lifelong learning developed by Paul Belanger (1994). The advantage of this framework is that it provides an all-inclusive, holistic approach to education and training and its starting point is the learners rather than the providers.

Lifelong learning is an integrative concept. 'Lifelong' means that learning and education are possible at any age-from the cradle to the grave. It is also integrative because it refers to learning both in the formal education system and through everyday life, either in the home, through a social movement, through work or through local community activities. It includes formal, non-formal and informal education. The concept, therefore, is integrative in two dimensions: horizontal (between home, community, the media and work) and vertical (between different life stages).

Belanger (1994, p.354) argues that lifelong learning is not a norm to prescribe but an empirical reality to analyse and reconstruct. Therefore, lifelong learning inevitably exists in all societies in different forms as people move through life's stages. He argues that there are many 'lifelong educations' as in each society lifelong learning refers to the totality of learning activities which can be broken down into three specific constituent elements:

(1) initial education;

(2) adult education; and

(3) the diffuse learning environments.

\section{Initial Education}

Belanger states that the basic fact behind lifelong learning is that educational development is a lifelong endeavour and tends to be a cumulative one. A circle is created: those who participate more in learning activities during the different periods of adult life tend to be those who had better and longer initial education. Those who have had more get more. Limited initial education tends to produce low rates of adult participation in formal and non-formal activities. Formal initial education tends to parcel people into different educational lifecourses. Precisely because the general cumulative pattern of educational participation is highly influenced by initial education, the critical progression of initial education will be an important point of reference in assessing the transition towards learning societies.

\section{Adult Education}

Probably one of the more significant trends in education over the last 20 years is the rapid expansion of the social demand for organized adult learning. According to Belanger (1994, p. 358) a real explosion has occurred in a variety of forms: higher demands for literacy, increasing requests for part-time registrations in post-secondary educational institutions, growing needs for training and retraining, dramatic increases in the demand for training courses in second or third languages, expanding numbers of women and men who wish to use their non-working time in achieving personal development goals, growth of training projects in varied associations and unions. Adult education in many countries becomes one of the poles of growth of educational systems. Such developments, however widespread, show 
several disparities between and within different countries, both industrialized and developing ones. Another important observation is that there are many different organizations involved in adult, formal and non-formal education in many countries. In sharp contrast to the organizational pattern of formal initial education, the provision of adult education, as well as non-formal initial education, is diffused over many different structures and arrangements. Often educational components are integrated into, for example, health, agriculture, women's projects, population programmes and environmental schemes.

\section{Diffuse Learning Environments}

Learning does not take place only through organized educational, formal or non-formal processes. Throughout life, informal learning events and processes take place. People live in different cultural contexts unevenly conducive to active learning. Thus concomitant to initial education and adult education and throughout the life-course there are also learning environments which have a relatively autonomous influence on the participation in educational activities and on the achievement of significant learning. It is the informal dimension of education, the learning contexts, be it the daily life environment of pre-school children or the norms and cultural orientations embedded in the different initial education and adult education settings. The attitude towards education and the predisposition to specific types of learning in the family or in the immediate environment, the mere availability of books and the prevailing attitudes to written communication, the presence of local cultural infrastructureall are cultural factors influencing educational aspirations and learning achievement, both in initial education and adult education.

The recognition of the three dimensions of learning environments, initial education and adult education and their relationships to one another leads to the acknowledgement that no educational policy can ignore the media, the other cultural industries, the libraries and the museums, as well as the cultural impact of the different urban or rural physical environments. The mutations in the educational systems from the perspective of lifelong learning are thus occurring through changes in initial education and adult education, but also through the tangibility of learning environments and through the changing relations between these three.

Belanger's lifelong learning framework can be located within the humanistic school. This is in contrast to the human capital school which talks of education in terms of the market and investment in human capital and reduces education to the needs of the economy. As Gustavsson (1997) argues, lifelong learning historically has been more closely associated with the humanistic strand which considers education from the perspective of the individual and the democratic citizen. Within the debates about lifelong learning both strands exist, but the drive to the marketization of education and training within a human capital perspective holds sway both globally and, increasingly, in South Africa. Using Belanger's framework, I now turn to describe the conditions of lifelong learning in South Africa.

\section{The Contexts for Lifelong Learning in South Africa}

Taking Belanger's argument, lifelong learning exists in South Africa. However, what its state of development is in any detail is unknown, as extensive research would be required into initial education, adult education and learning environments, and their interrelationships. But there are several well-known facts about South African life which can throw light on the question of how conducive the contexts are for lifelong learning in South Africa today. All aspects of education and training in South Africa have been shaped very directly by its colonial, segregationist and apartheid past. The legacies of these are extensive. It is not 
appropriate here to list these but I will mention some aspects in order to sketch the conditions for lifelong learning (e.g. Kallaway, 1984; Kallaway et al., 1997).

\section{Initial Education}

There has been a rapid expansion over the last 20 years of schooling for black people in South Africa. However, the quality of this education for the most part has been abysmal. It is recognized that the culture of learning has been virtually non-existent in many schools as a result of the years of political and economic turbulence. There are still over two million children between the ages of 7 and 15 years out of school (Fataar, 1997). The provision of early childhood education is extremely limited. It is acknowledged that of all the crimes inflicted on the majority of South Africans by apartheid policies, one of the most devastating must have been the imposition of 'Bantu education'. It will take many years to counter the systematic educational deprivation that was the result for millions of South Africans. While quantitatively numbers expanded rapidly, success rates have been poor with the adult functional illiteracy rate being projected at about $30 \%$ on average, with $50 \%$ of black African women having no more than 7 years of schooling (Harley \& Aitchison, 1996).

To change schooling from a fragmented, racialized system to an integrated one is a Herculean and complex task for the new national and provincial Departments of Education. They have launched an ambitious programme to implement a new curriculum throughout the system which will move from a content-based curriculum to one based on outcomes. This is called 'Curriculum 2005: lifelong learning for the 21st century'. It speaks about lifelong learning by which it means both that adults and out-of-school youth can benefit from the system and that there will be linkages to the newly formed National Qualifications Framework (NQF).

With initial education being a crucial element in the continuous learning of the population, the state of initial education in South Africa is a critical dimension. At present the harsh fiscal reality means that the new Departments of Education have managed, according to the Deputy Director General Rensburg, to get one million additional pupils into the system but they have not yet improved the quality. This means that for the majority of learners initial education is still very poor, which has a direct effect on their educational life-chances. The quality of initial education will need to improve dramatically if greater numbers of adults are to become active learners.

\section{Adult Education}

The major actors within the history of adult education in South Africa have been organizations of civil society, the state, and the economy. The history reflects simultaneous activities which are often in direct conflict with one another, being driven by different social, political and economic interests (Gush \& Walters, 1998).

Much of the adult educational activity has been in response to social class, race, and gender inequalities and has been led by organizations of civil society, including trade unions, tertiary education institutions, political organizations, non-governmental organizations (NGOs), religious groupings, and community-based organizations. It has been strongly motivated within particular ideological frameworks, for example, by the Communist Party of South Africa (CPSA) in the 1920s and 1930s, or by the Christian missionaries who set up literacy NGOs in the 1950s. It has been mainly of an informal or non-formal kind within different social movements. The government between the 1950 s and the early 1980s systematically shut down any attempts to educate black adults. It harassed learners and 
teachers through legislation of various kinds, banning orders, and a vast array of repressive mechanisms. A vibrant NGO literacy movement has struggled against enormous odds to provide adult literacy services to barely $1 \%$ of those in need.

Since 1910 the various governments have invested minimally in adult education. At times of major political, social or economic crises the importance of adult education has gained some recognition, but few sustained investments have been made in it. Within the economy, adult education and training have never been supported strongly. Incentives to encourage spending on training of the workforce have been few. For many decades, as the industrialization of the economy occurred, the need for skilled people has been met by the importation of skilled white immigrants from Europe, thus not requiring much investment in education and training by companies. In the 1980s, because of economic need and pressure from the trade unions, adult education and training gained in prominence at the workplace. In the 1990s, several trade unions had education and training demands as part of their negotiations with employers. The major trade union federation, the Congress of South African Trade Unions (COSATU), gave important leadership in the shaping of policy debates in the early 1990s. Together with the employers and providers of adult education within the National Training Board, a national training strategy has been developed within a lifelong learning framework.

A cornerstone of the new system is the Skills Development Strategy for Economic and Employment Growth in South Africa (hereafter referred to as SDS) which has been proposed by the Department of Labour and was translated into legislation in 1998. It is trying to realize a vision of an integrated skills development system which promotes economic and employment growth and social development through a focus on education, training and employment services'. It plans to create a national training fund through a levy of the payroll of mainly private sector companies. It is a mechanism to ensure that the private sector does invest in training. Eighty per cent of the levy collected will be earmarked for enterprise-based training as well as for entry level skills in that particular industry. The remaining $20 \%$ of the total levy revenue will go to a National Skills Fund to fund 'training targeted at priority skill needs within industry, which are identified by government and the National Skills Authority'. The SDS proposal affords the government significant leverage over the development of a systematic and comprehensive skills development strategy while relying on enterprise funding (Soobrayan, 1997, p. 255).

Central to the architecture of transformation of the new education and training system is the NQF 'which will make it possible for all learners irrespective of their age to realize the goal of lifelong learning' (Isaacs, 1997, p. 270). The objectives of the NQF are to:

(a) create an integrated national framework for learning achievements;

(b) facilitate access to, mobility and progression within education, training and career paths;

(c) enhance the quality of education and training;

(d) accelerate the redress of past unfair discrimination in education, training and employment opportunities; and thereby

(e) contribute to the full personal development of each learner and the social and economic development for the nation at large (Clause 2 of the South African Qualifications Authority Act).

The development of the NQF is in its early stages, but is critical to the integration of education and training and the facilitation of horizontal and vertical mobility of learners. It has identified 'critical cross field outcomes' that need to be embedded within registered unit standards across all fields. These include competencies for lifelong learners, such as problem 
solving, working with others, communicating effectively, analysing, organizing and critically evaluating information.

Further spheres of policy development are within the further education and training (FET) sector and adult basic education and training (ABET). The country's Constitution states clearly that everyone has a right: 'to a basic education, including adult basic education, and to further education, which the state, through reasonable measures, must make progressively available and accessible' (The Constitution of RSA, 1996, p. 14).

Within the FET sector there was a Green Paper which was submitted to government to facilitate the transformation process. As it says, 'If the FET is to fulfil its role in promoting lifelong learning, personal development, economic growth, nation-building and the creation of a just and equitable society, it must be transformed' (Department of Education, 1998, p. 2). The FET sector, which includes networks of technical colleges, has also been highly racialized and inadequate to meet the needs of the majority. Likewise, the ABET sector has been largely ignored in the past and is now attempting to gear up to meet the challenges of reaching $30 \%$ of the adult population who are not functionally literate. They see ABET as both part of and a foundation for lifelong learning (Directorate for Adult Education and Training, 1997). Within various government departments, like Water Affairs, Land and Agricultural Affairs, Arts and Culture, Health, there are also various programmes for capacity building and training at ABET levels.

The higher education sector is also in the throes of being transformed into a national system which will seek to contribute to economic development, redress and attainment of social equality. It too mentions the importance of contributing to a system of lifelong learning.

In summary, adult education for the majority of South Africans has been seriously neglected, with little investment in adult education and training. Recently enormous efforts have been made to conceptualize and construct a new integrated system which aims to facilitate lifelong learning. However, the policy frameworks are still being finalized and building blocks being laid for implementation. It will take time, ongoing investments, and political commitment to achieve an adequate infrastructure for adult education provision.

\section{Learning Environments}

The learning environments for the majority of the population who live in varying degrees of poverty, have been particularly limited. It is not unusual for there to be no books in homes, poorly equipped libraries in communities, overcrowded living conditions, and so on. Just the other day, one of our students described how she has to get up at 2 am to study because she shares a room with six others. Very few black South Africans would have been exposed, for example, to cultural activities linked to museums and art galleries. There have over the years been small attempts by NGOs to get people out of the township ghettos in order to counter various forms of cultural deprivation. The conditions are of course very different for rural and urban communities with rural people being far worse off.

There are now 11 official languages, whereas before there were two. Previously the majority of people did not have their languages affirmed and often had to learn through their second or third languages. There have been very limited institutionalized language learning facilities. Most language skills are learnt through everyday interaction.

Although the conditions for the majority have been and still are generally appalling, there have been strong organizations of civil society in which a significant number of people have participated. These include religious, economic, cultural and political organizations. Informal learning has occurred through these. The indigenous churches, burial societies and the trade 
union movement are examples of important vehicles for informal learning amongst the population.

Previously the national media were very tightly controlled by the apartheid government. Now there has been an opening up of control of the media and an encouragement of the growth of community radios. Thirty new stations have been established recently which will be contributing in various ways to the affirmation of local knowledges, needs and interests.

It is very difficult to know within this transition period how far the new developments are contributing to improving the quality of learning within the diffuse environments. Also, to know what the interrelationships are between initial education, adult education and the broader environment. At this stage it is fair to say that the expectations of the majority of adults are that education is not for them, but for their children. Most of the women and men are trying to survive and this takes all their time. In a recent study (Breier et al., 1996) amongst taxi drivers, it was clear that although they might wish to become literate and numerate, there was no opportunity in a day that started at $5 \mathrm{am}$ and ended at $10 \mathrm{pm}$. The economic imperatives prevented them from even considering any form of institutionalized learning. They rely very much on supportive environments which enable informal learning and exchange networks. But given their poor initial education, and the largely unsupportive learning environment, their abilities to maximize informal learning opportunities will no doubt be limited.

\section{Prospects for Lifelong Learning in South Africa}

Reading education policy documents in various parts of the world, including South Africa, lifelong learning often seems a panacea: it will help career development, cure unemployment, encourage flexibility and change, raise personal and national competitiveness, help personal development, and so on. It has become 'policy speak' which assumes multiple meanings and interpretations. The argument for a lifelong learning system, which is reflected in the new education and training legislation, is made in terms of the imperatives, firstly, to redress the apartheid past, secondly, to strive for social equity and, thirdly, to achieve economic competitiveness.

In South Africa there has been a rigorous debate about the importance of not juxtaposing economic development with the achievement of social justice as contained in the notions of equity and redress. There has been a convincing argument that we must recognize the competing claims of both equality and economic development which inevitably are in tension (Walters, 1996). In the South African context, it has been argued that equality cannot be achieved without economic development and economic development amongst the majority of people cannot be achieved without striving to achieve equality. Therefore, for the majority to benefit, an approach to economic and social development must recognize the interrelatedness of society and the economy where human values not human capital predominate. This is the ultimate challenge for lifelong learning.

While there has been the government's Reconstruction and Development Programme (African National Congress, 1994) which argued for a people-driven process of development which would meet basic needs, develop human resources, build the economy and democratize the state and society, it did not take long for a new macro-economic policy to be adopted which foregrounded economic growth and fiscal constraint. This has meant that the prospects for translating many of the fine-sounding policies into lifelong learning practices have decreased substantially as financial stringency has become the common refrain.

For lifelong learning to deepen for more than a small group of well-educated, mainly urban, formally employed people, initial education, adult education and the learning 
environments of all the people will have to be improved. If this does not happen, then at least two polarized 'lifelong educations' will result. One will be located powerfully within a human capital frame and will focus largely on formal sector employment within the large companies. The other will be a much weaker, less resourced one which will be for the poor majority. The majority of women would be located in the latter. A broader integrated view is imperative if the humanistic democratic goals of lifelong learning are to be achieved. Utilizing Belanger's framework, which acknowledges the daily lived realities of women and men, is a helpful way of retaining an holistic and integrated vision of lifelong learning in South Africa and elsewhere.

\section{REFERENCES}

African National Congress (1994) Reconstruction and Development Programme (Johannesburg, ANC).

Belanger, P. (1994) Lifelong learning: the dialectics of 'Lifelong Educations', International Review of Education, 41, pp. 353-381.

BREIER, M., TAETSANE, M. \& SAIT, L. (1996) Taking literacy for a ride-reading and writing in the taxi industry, in: M. PRINSLOo \& M. BREIER (Eds) The Social Uses of Literacy (Johannesburg, SACHED Books and John Benjamins Publishing Company).

CANDY, P.C. (n.d.) Lifelong education and the university sector, a discussion paper for the National Commission on Higher Education, South Africa.

Department of Education (1998) Green Paper on Further Education and Training (Pretoria), Department of Education).

Directorate for Adult Education and Training (1997) Policy for Adult Basic Education and Training (Pretoria, Directorate for Adult Education and Training).

FAtAaR, A. (1997) Access to schooling in a post-apartheid South Africa: linking concepts to contexts, in: P. Kallaway, G. Kruss, A. Fataar \& G. Donn (Eds) Education After Apartheid, pp. 68-85 (Cape Town, University of Cape Town Press).

Gush, C. \& Walters, S. (1998) South Africa, in: J. Draper (Ed.) Africa Adult Education. Chronologies in Commonwealth countries, pp. 77-86 (Cape Town, CACE Publications).

Gustavsson, B. (1997) Lifelong learning reconsidered, in: S. WALters (Ed.) Globalization, Adult Education and Training. Impacts and issues, pp. 237-249 (London, Zed Books).

Harley, A. \& Artchison, J. (1996) A Survey of Adult Basic Education in South Africa in the 1990s (Johannesburg, SACHED Books).

IsAACS, S. (1997) Global indicators to the transition of lifelong learning in South Africa, in: NATIONAL INSTITUTE FOR Educational RESEARCh IN JAPAN \& UNESCO INSTITUTE FOR EduCATION (Eds) Comparative Studies on Lifelong Learning Policies, pp. 269-282 (Tokyo, UIE and National Institute for Educational Research of Japan).

Kallaway, P. (Ed.) (1984) Apartheid and Education (Johannesburg, Ravan Press).

Kallaway, P., KRuss, G., FataAr, A. \& Donn, G. (1997) Education after Apartheid (Cape Town, University of Cape Town Press).

SoobrayAN, B. (1997) From apartheid education to lifelong learning: assessing the ameliorative potential of emerging education policy in South Africa, in: Lifelong Learning: reality, rhetoric and public policy. Conference Proceedings (Guildford, University of Surrey).

The Constitution of the Republic of South Africa Act 108 of 1996 (Pretoria, South Africa).

WALters, S. (1996) Balancing equality and development in universities after apartheid in: J. ELLIOT, H. FRANCIS, R. Humphreys \& D. Istance (Eds) Communities and their Universities, pp. 118-134 (London, Lawrence and Wishart). 